[Agr. Biol. Chem., Vol. 36, No. 6, p. 961 966, 1972]

\title{
Conditions of Oxygen Supply in L-Glutamic Acid Fermentation from Hydrocarbon
}

\author{
By Kaetsu Kobayashi, Shigeo Ikeda, Kazuo Hishinuma, \\ Yoshio Hirose and Hiroshi OKadA \\ Central Research Laboratories of Ajinomoto Co., Inc. \\ Kawasaki, Japan \\ Received November 12, 1971
}

\begin{abstract}
A small jar fermentor was developed in order to investigate the effect of oxygen supply on hydrocarbon fermentation. Several indices to oxygen transfer were examined with this small jar fermentor. Conditions for suitable oxygen supply were examined in L-glutamic acid fermentation from hydrocarbon by use of shaking flasks and these small jar fermentors. The data indicated that the rate of oxygen transfer ought to be more than $14.3 \times 10^{-7}$ mole $/ \mathrm{ml} \cdot \mathrm{min}$ in order to obtain satisfactory results. The coefficient of oxygen transfer rate ( $\left.K_{L a} / H\right)$ decreased as the fermentation went on, so the supply of oxygen enriched gas mixture was effective to increase the production of L-glutamic acid.
\end{abstract}

It is well known that a great deal of oxygen is required in hydrocarbon fermentation. Darlington ${ }^{11}$ and Guenther ${ }^{2 \prime}$ have calculated that about three times more oxygen was needed in hydrocarbon fermentation than in carbohydrate fermentation. Mimura ${ }^{3 !}$ has demonstrated this fact with Candida petrophilum in cell mass production. Although there are investigation $\mathrm{s}^{4-6)}$ concerning the oxygen demand of microorganisms in the field of production of cell mass, there are very few in other fields of hydrocarbon fermentation.

The present paper is concerned with the development of a small jar fermentor which is suitable to study the hydrocarbon fermentation, and conditions of oxygen supply in L-glutamic acid fermentation from hydrocarbon.

\section{MATERIALS AND METHODS}

Microorganism employed in this study was Corynebacterium hydrocarboclastus R-7 UV PC.r.-10. This strain was a penicillin-resistant mutant and the isolation of this strain from the parent strain was described in the previous paper. ${ }^{71}$ Cultivation of this bacterium was performed according to the method described in the previous paper. ${ }^{7}$ The composition of media is given in Table I. Partial pressure of oxygen in gas- and liquid-phase ( $P_{f}$ and $P_{L}$, respectively) was determined

Table 1. Composition of the Basal Medium

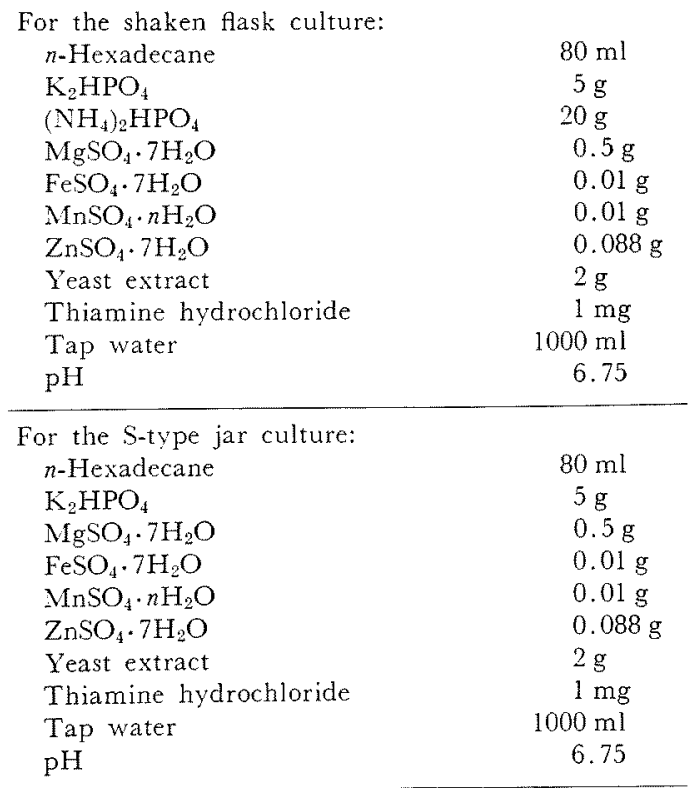


using a Beckman 777 Oxygen Analyzer. Oxygen transfer rate $r_{\mathrm{ab}}(\mathrm{mole} / \mathrm{ml} \cdot \mathrm{min})$ and oxygen demand $\mathrm{KrM}(\mathrm{mole} / \mathrm{ml} \cdot \mathrm{min})$ were evaluated by the unsteadystate gas analysis method. ${ }^{81}$ Sulfite oxidation experiments were performed with the reaction mixture of K. Yamada et al. ${ }^{9}$ The other analytical methods were the same as already reported. ${ }^{7,10}$

\section{RESULTS AND DISCUSSION}

\section{Development of a small jar fermentor}

A small jar fermentor was developed in order to investigate the effect of oxygen supply on L-glutamic acid fermentation from hydrocarbon

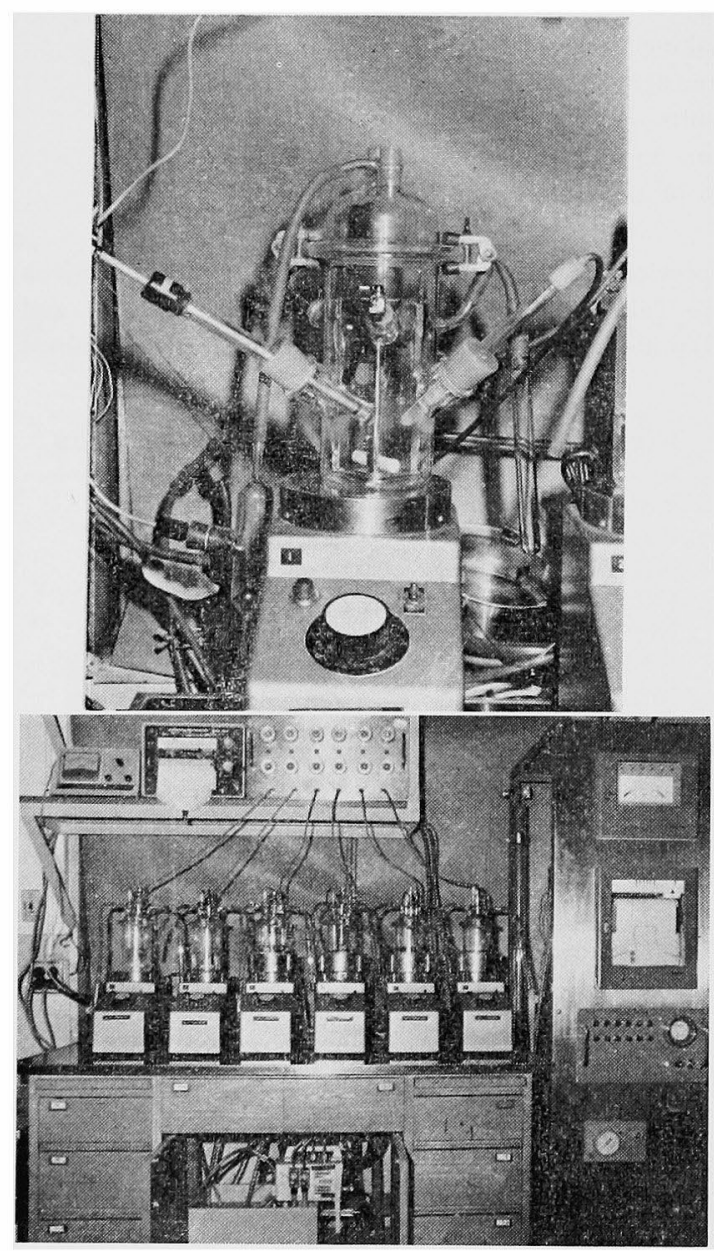

FIG. 1. The S-Type Jar Fermentor.

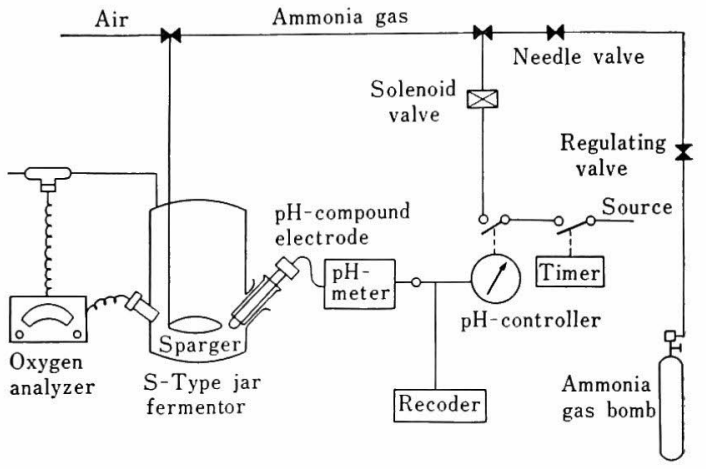

FIG. 2. $\mathrm{pH}$ Control and Oxygen Analysis System of the S-Type Jar Fermentor.

as well as to obtain the data for scale-up.

This jar fermentor (hereafter called the Stype jar) was made of glass and the total volume was approximately $1000 \mathrm{ml}$ as shown in Fig. 1. The S-type jar fermentor consisted of many equipments such as, the aeration and agitation, the sampling and feeding, the temperature and $\mathrm{pH}$ controlling as well as the oxygen analyzing modules. The diagram of a part of these systems was illustrated in Fig. 2.

Usually, a great effort and a long period were required for the scale-up of the fermentation from the shaking culture to the commercial tank culture, because there were many differences between them. So, a number of pilot-plant jar fermentors were employed in order to obtain the data for the scale-up. The effort and period would be saved by the use of S-type jar fermentors, because these small jar fermentors have almost the same functions as the pilot-plant jar fermentors. In addition, S-type jar fermentors occupy less space and less man-power.

The agitation was made by an impeller driven magnetic force. This agitation system had many advantages in hydrocarbon fermentation over the ordinary mechanical agitation system; it was free from the troubles such as the leakage of air and hydrocarbon vapor, the contamination of other microbes and the dissolution of grease for the mechanical seal of 
the driving system.

Figure 3 shows the values of sulfite $r_{\mathrm{ab}}$ under the various conditions of aeration and agitation. The sulfite $r_{\mathrm{ab}}$ of the S-type jar fermentor was affected strongly by the number of revolution in comparison with that of the pilot-plant jar fermentor. Another characteristic was that a greater part of oxygen transfer was made from liquid surface into the liquid. This was due to the existence of the large free surface per unit liquid volume. Values of $K d\left(=K_{L} a / H\right)$ where $K_{L} a$ was overall oxygen transfer coefficient across gas-liquid interface (liter $/ \mathrm{min}$ )

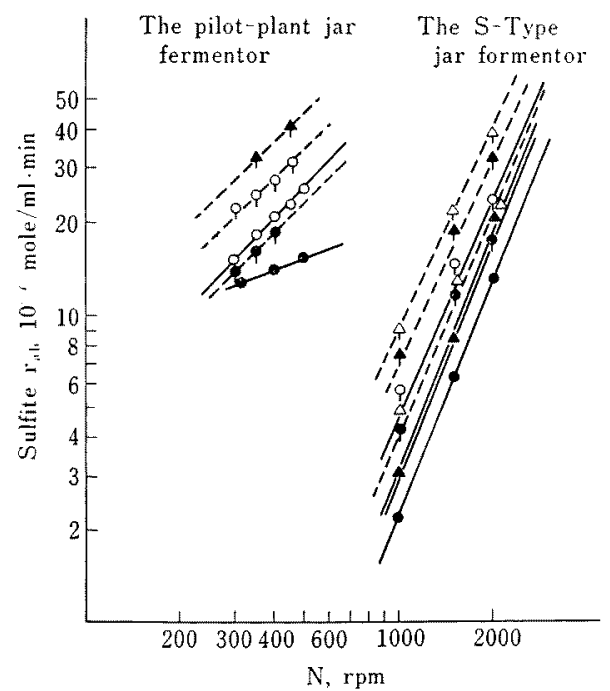

FIG. 3. Sulfte $r_{a b}$ under the Various Conditions.

- Air flow rate $1 / 4 \mathrm{v} / \mathrm{v} \cdot \mathrm{min}$, turbine type impeller

- Air flow rate $1 / 4 \mathrm{v} / \mathrm{v} \cdot \mathrm{min}$, paddle type impeller

O-O Air flow rate $1 / 2 \mathrm{v} / \mathrm{v} \cdot \mathrm{min}$, turbine type impeller

O-o Air flow rate $1 / 2 \mathrm{v} / \mathrm{v} \cdot \mathrm{min}$, paddle type impeller

$\Delta$-A Air flow rate $1 / 1 \mathrm{v} / \mathrm{v} \cdot \mathrm{min}$, turbine type impeller

A--A Air flow rate $1 / 1 \mathrm{v} / \mathrm{v} \cdot \mathrm{min}$, paddle type impeller

$\triangle \rightarrow \triangle$ Air flow rate $2 / 1 \mathrm{v} / \mathrm{v} \cdot \mathrm{min}$, turbine type impeller

$\triangle-\triangle$ Air flow rate $2 / 1 \mathrm{v} / \mathrm{v} \cdot \mathrm{min}$, paddle type impeller and $H$ was Henry's constant (atm $\cdot \mathrm{ml} / \mathrm{mole}$ ) were estimated under two conditions; the usual aeration through the sparger and the ventilation of gaseous phase over the liquid phase. Supposing that $K d$ value of the latter indicates the oxygen transfer from liquid surface, the percentage of oxygen transfer from liquid surface in overall oxygen transfer could be calculated from these two $K d$ values. More than $90 \%$ of oxygen was transferred from liquid surface in the S-type jar fermentor, whereas its percentage in the pilot-plant jar fermentor was less than $100^{\circ}$, as shown in Table II. Accordingly, three types of oxygen supply were possible; through the sparger, ventilation of gaseous phase over the liquid of the vessel and through the cotton

TABle II. Comparison of The S-Type JaR FERMENTOR AND THE PILOT-Plant Jar FERMENTOR IN THE MODE OF OXYGEN TRANSFER

\begin{tabular}{lcc}
\hline & $\begin{array}{c}\text { The S-type } \\
\text { jar fermentor }\end{array}$ & $\begin{array}{c}\text { The pilot-plant } \\
\text { jar fermentor }\end{array}$ \\
& 300 & $30 \times 10^{3}$ \\
\hline $\begin{array}{l}\text { Liquid volume }(\mathrm{ml}) \\
\text { Free surface per unit } \\
\text { volume (cm } / \mathrm{liter})\end{array}$ & 185 & 31.8 \\
$\begin{array}{l}\text { Depth of liquid }(\mathrm{cm}) \\
\text { Sulfite } K d(\mathrm{t}) \\
\quad \text { (mole } / \mathrm{ml} \cdot \mathrm{min} \cdot \mathrm{atm})\end{array}$ & 5.4 & 31.5 \\
$\begin{array}{l}\text { Sulfite } K d(\mathrm{~g}) \\
(\mathrm{mole} / \mathrm{ml} \cdot \mathrm{min} \cdot \mathrm{atm})\end{array}$ & $9.9 \times 10^{-6}$ & $1.2 \times 10^{-6}$ \\
$K d(\mathrm{~g}) / K d(\mathrm{t}) \times 100$ & 93 & 9
\end{tabular}

S-type jar fermentor: $1 / 2 \mathrm{v} / \mathrm{v} \cdot \mathrm{min}, 1500 \mathrm{rpm}, 1$ $\mathrm{kg} / \mathrm{cm}^{2}$.

70 liter jar fermentor: $1 / 2 \mathrm{v} / \mathrm{v} \cdot \mathrm{min}, 370 \mathrm{rpm}, 1.5$ $\mathrm{kg} / \mathrm{cm}^{2}$.

$K d(\mathrm{t})$ : Total $K d$ value measured under the aeration through the sparger as shown in Fig. A.

$K d(\mathrm{~g}): \quad K d$ value measured under the ventilation of gaseous phase as shown in Fig. B.

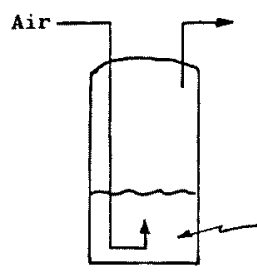

FIG. A.

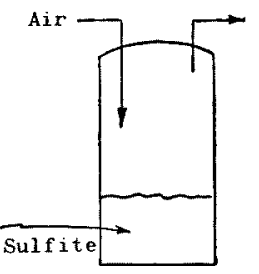

FIG. B. 


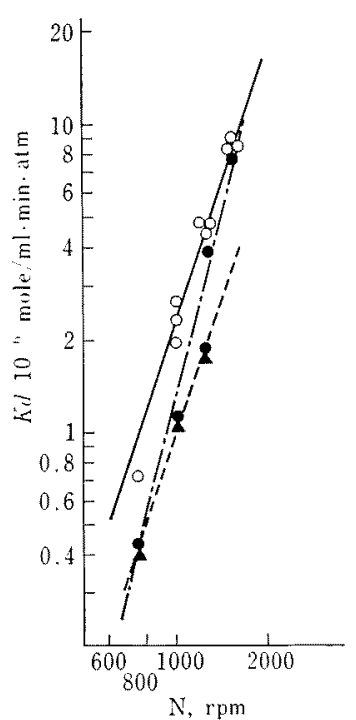

FIG. 4. Comparison of Three Types of Aeration.

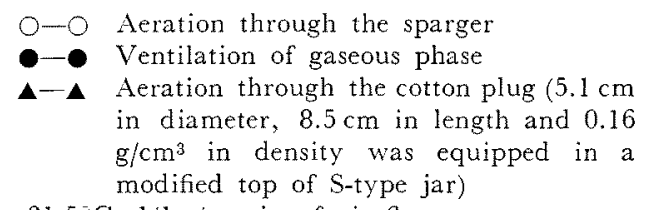

at $31.5^{\circ} \mathrm{C}, 1 / 1 \mathrm{v} / \mathrm{v} \cdot \mathrm{min}$ of air flow rate plug. $K d$ values under these conditions are shown in Fig. 4.

Effects of oxygen supply on L-glutamic acid production and cell growth

L-Glutamic acid fermentation was performed under various conditions of oxygen supply which were attained by selecting suitable volumes of culture fluid and employing different types of cotton plugs of shaking flasks. The condition of oxygen supply was expressed in sulfite $r_{\mathrm{ab} .}{ }^{11)}$ As shown in Table III, the condition of oxygen supply exerted a great influence on L-glutamic acid production and cell growth. When sulfite $r_{a b}$ was less than $14 \times 10^{-7} \mathrm{~mole} / \mathrm{ml} \cdot \mathrm{min}$, the sufficient production of L-glutamic acid was not accomplished as shown in Fig. 5. Effects of oxygen supply at the earlier phase (growth phase) and at the later phase (production phase) of fermentation were examined. Fermentations were carried out under the conditions of oxygen supply at $5.3,10.5$ and $14.3 \times 10^{-7} \mathrm{~mole} / \mathrm{ml} \cdot \mathrm{min}$ as sulfite $r_{\mathrm{ab}}$ in the growth phase (before the addition of penicillin) and then oxygen supply was changed to the various levels in order to know effects at the production phase. As shown in Fig. 6,

Table III. Effects of Oxygen Supply on l-Glutamic Acid Production and Cell Growth

\begin{tabular}{|c|c|c|c|c|}
\hline Gas phase characteristics & $\begin{array}{c}V_{L} \\
(\mathrm{ml})\end{array}$ & $\begin{array}{c}\text { Sulfite } r_{\mathrm{ab}} \\
(\mathrm{mole} / \mathrm{ml} \cdot \mathrm{min})\end{array}$ & $\begin{array}{l}\text { L-Glutamic } \\
\text { acid }(g / \text { liter })\end{array}$ & $\begin{array}{c}\text { Dried cell } \\
\text { weight }(\mathrm{g} / \text { liter })\end{array}$ \\
\hline \multirow[t]{2}{*}{ Cotton plugs of type A were equipped } & 40 & $1.2 \times 10^{-7}$ & 1.0 & 4.1 \\
\hline & 20 & $2.3 \times 10^{-7}$ & 0.9 & 5.6 \\
\hline \multirow[t]{2}{*}{ Cotton plugs of type $B$ were equipped } & 40 & $3.0 \times 10^{-7}$ & 1.0 & 5.3 \\
\hline & 20 & $5.3 \times 10^{-4}$ & 6.3 & 7.0 \\
\hline \multirow[t]{2}{*}{ Cotton plugs of type $\mathrm{C}$ were equipped } & 40 & $6.5 \times 10^{-7}$ & 10.6 & 6.0 \\
\hline & 20 & $10.5 \times 10^{-7}$ & 21.6 & 9.7 \\
\hline \multirow[t]{3}{*}{ Air was employed for puring flasks } & 80 & $7.1 \times 10^{-7}$ & 17.6 & 7.3 \\
\hline & 40 & $10.0 \times 10^{-7}$ & 21.3 & 7.7 \\
\hline & 20 & $14.3 \times 10^{-7}$ & 23.7 & 10.3 \\
\hline \multirow{3}{*}{500 of oxygen gas was employed for purging flasks } & 80 & $16.9 \times 10^{-7}$ & 21.8 & 9.1 \\
\hline & 40 & $23.9 \times 10^{-7}$ & 20.9 & 8.7 \\
\hline & 20 & $34.1 \times 10^{-7}$ & 23.0 & 8.9 \\
\hline
\end{tabular}

Cotton plugs, type A: $0.4 \mathrm{~cm}$ in diameter and $3 \mathrm{~cm}$ in length, $0.52 \mathrm{~g} / \mathrm{cm}^{3}$ in density.

Cotton plugs, type B: $0.8 \mathrm{~cm}$ in diameter and $3 \mathrm{~cm}$ in length, $0.16 \mathrm{~g} / \mathrm{cm}^{3}$ in density.

Cotton plugs, type C: $2.4 \mathrm{~cm}$ in diameter and $4.5 \mathrm{~cm}$ in length, $0.16 \mathrm{~g} / \mathrm{cm}^{3}$ in density. 


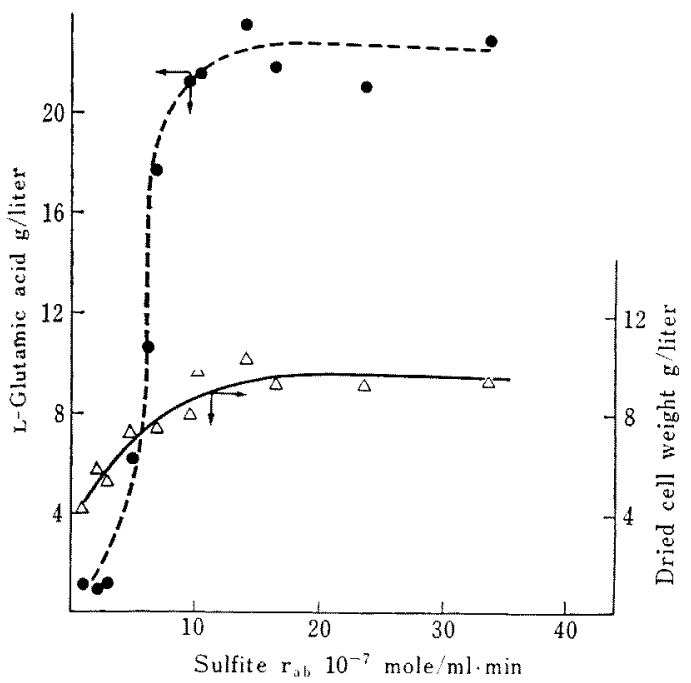

FIG. 5. Relationship between $r_{a b}$ Values and Fermentation Results.

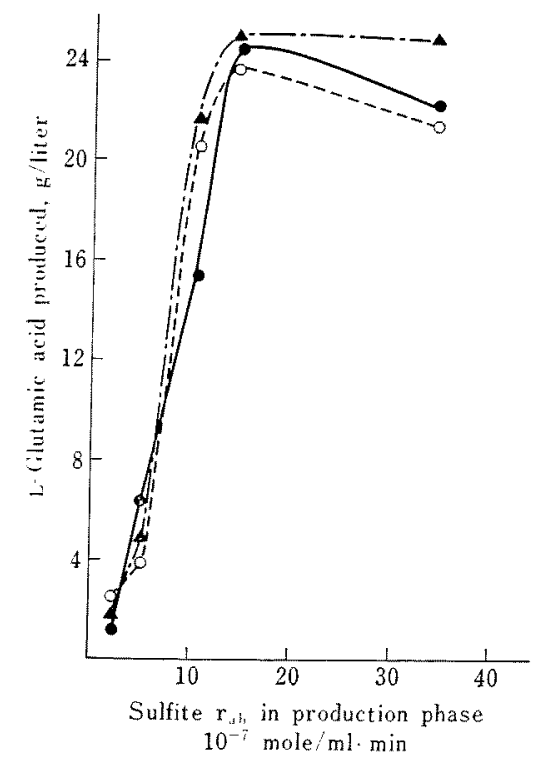

F1G. 6. Effects of Oxygen Supply in Production Phase on L-Glutamic Acid Fermentation.

Sulfite $r_{a b}$ in growth phase

- $5.3 \times 10^{-4} \mathrm{~mole} / \mathrm{ml} \cdot \mathrm{min}$

O-- $10.5 \times 10^{-7} \mathrm{~mole} / \mathrm{ml} \cdot \mathrm{min}$

A-.-A $14.3 \% 10^{-7} \mathrm{molc} / \mathrm{ml} \cdot \mathrm{min}$ the amount of L-glutamic acid was determined by the level of oxygen supply at the production phase irrespective of that at the growth phase. To attain the maximum productivity, the rate of oxygen transfer ought to be more than $14.3 \times 10^{-7} \mathrm{~mole} / \mathrm{ml} \cdot \mathrm{min}$.

\section{L-Glutamic acid fermentation under sufficient oxygen} transfer

L-Glutamic acid fermentation was performed using S-type jar fermentors under the aeration of $1 / 1 \mathrm{v} / \mathrm{v} \cdot \mathrm{min}$ and the agitation of $1500 \mathrm{rpm}$ which gave sulfite $r_{\mathrm{ab}}$ of $20 \times 10^{-7} \mathrm{~mole} / \mathrm{ml} \cdot \mathrm{min}$. Although $\mathrm{pH}$ was maintained at the optimum level of 6.75 and oxygen supply was improved, L-glutamic acid production in the S-type jar fermentor did not increase so much as compared with the results obtained in the shaken flask culture. Shortage of oxygen supply was observedd in the course of fermentation. Dissolved oxygen became zero even though biological $r_{\mathrm{a}}$ was less than $20 \times 10^{-7} \mathrm{~mole} / \mathrm{ml} \cdot \mathrm{min}$. Disagreement in values of sulfite $r_{\mathrm{ab}}$ and biological $r_{\mathrm{ab}}$ suggested a difference in the property of the fermentation liquid. Biological $K d$ was calculated according to the following equation.

$$
\text { Biological } r_{u \mathrm{~b}}=\text { Biological } K d \times\left(P_{f}-P_{L}\right)
$$

As shown in Fig. 7, biological $K d$ value decreased as fermentation went on and it became about $1 \times 10^{-6} \mathrm{~mole} / \mathrm{ml} \cdot \mathrm{min} \cdot \mathrm{atm}$ after $30 \mathrm{hr}$

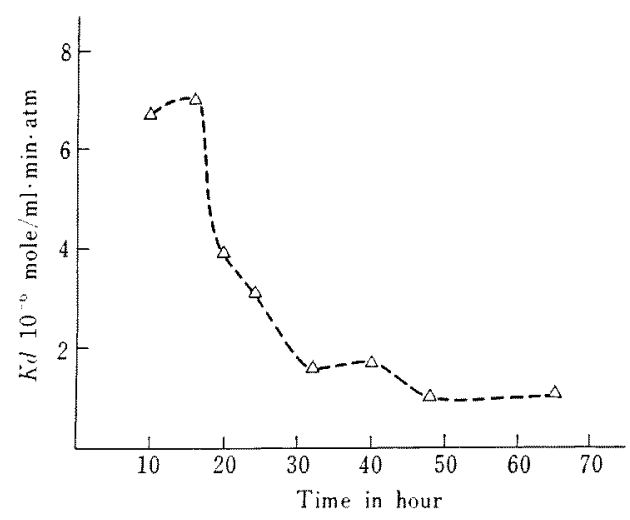

Fig. 7. Time Course of $K d$ Value. 


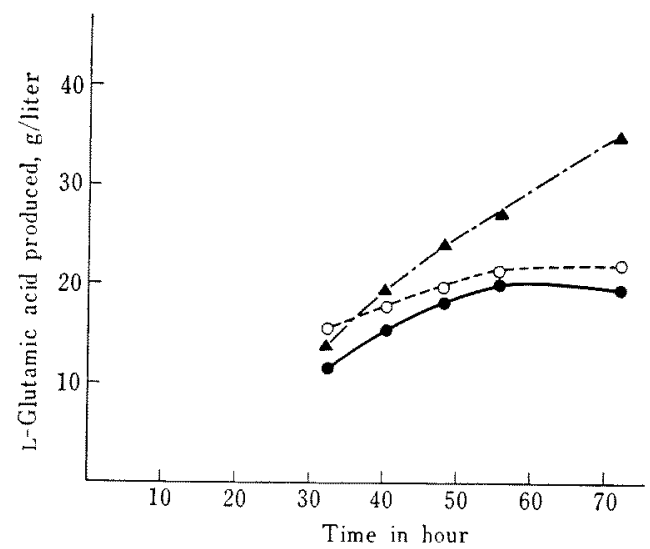

FIG. 8. Effects of $P_{f}$ on L-Glutamic Acid Production.

$\Delta-\cdot P_{f}=0.40 \mathrm{~atm}$

O-O $P_{f}=0.30 \mathrm{~atm}$

- $P_{f}=0.21 \mathrm{~atm}$

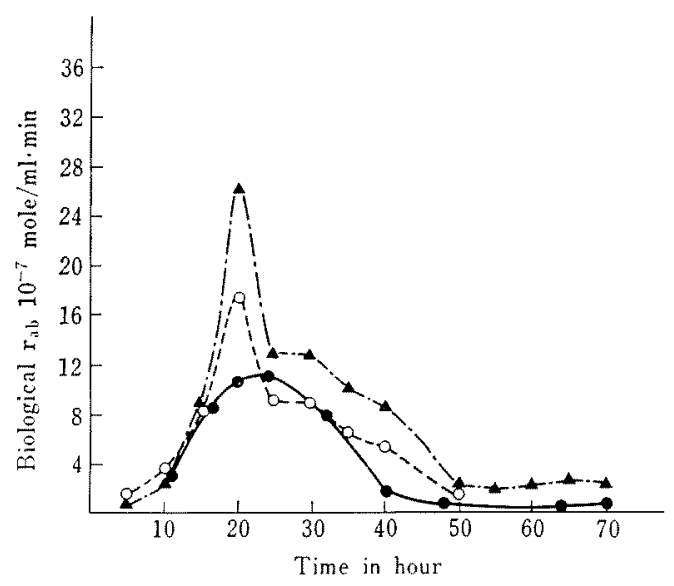

FIG. 9. Effects of $P_{f}$ on Biological iab.

A- - A $P_{f}=0.40 \mathrm{~atm}$

$0-0 \quad P_{f}=0.30 \mathrm{~atm}$

- $P_{f}=0.21 \mathrm{~atm}$ cultivation.

Improvement of oxygen supply was attempted by means of the aeration using oxygen enriched gas mixture. Oxygen and nitrogen gas mixtures which contained $21 \%, 30 \%$ and $40 \%$ of oxygen respectively were introduced into the fermentation liquid. L-Glutamic acid production and biological $r_{\mathrm{ab}}$ value increased as the oxygen content of gas mixture increased (Figs. 8, 9). Maximum L-glutamic acid production was $35 \mathrm{~g} /$ liter and maximum biological $r_{a b}$ value was $26 \times 10^{-7} \mathrm{~mole} / \mathrm{ml} \cdot \mathrm{min}$. The oxygen supply seemed to be a limiting factor in this fermentation and the supply of oxygen enriched gas mixture gave good results.

Acknowledgement. The authors wish to express their sincere thanks to Dr. Koichi Yamada, Professor of Tokyo University, for his continuing guidance and encouragement, and they also thank Mr. T. Koshimizu for his excellent technical assistance during the course of this work.

\section{REFERENCES}

1) W.A. Darlington, Biotechnol. Bioeng., 6, 241 (1964).

2) K. R. Guenther, ibid., 7, 445 (1965).

3) A. Mimura, J. Ferment. Technol., 49, 245 (1971).

4) T. L. Miller and M. J. Johnson, Biotechnol. Bioeng., 8, 567 (1966).

5) M.J. Johnson, Chem. Ind. (London), 1964, 1532.

6) D. C. Wang, Chem. Eng., 75, 99 (1968).

7) K. Kobayashi, S. Ikeda, K. Takinami, Y. Hirose and T. Shiro, Agr. Biol. Chem., 35, 1241 (1971).

8) I. Hirose, H. Sonoda, K. Kinoshita and $H$. Okada, ibid., 30, 49 (1966).

9) K. Yamada, J. Takahashi and H. Okada, J. Agr. Chem. Soc. Japan, 27, 703 (1953).

10) S. Ikeda, Y. Hirose, K. Kobayashi and K. Kinoshita, Agr. Biol. Chem., 33, 1042 (1969).

11) Y. Hirose, H. Sonoda, K. Kinoshita and $H$. Okada, ibid., 30, 583 (1966). 